\title{
PENGARUH KEYAKINAN KESEHATAN TENTANG KANKER SERVIKS TERHADAP PENERIMAAN VAKSIN HPV SDN LEMAHDUHUR I DAN TUNGGAKJATI II DI KABUPATEN KARAWANG
}

\author{
Dedy Frianto*, Rosmayanti, Himyatul Hidayah \\ Fakultas Farmasi, Universitas Buana Perjuangan Karawang, Karawang, Jawa Barat, \\ Indonesia. \\ *Penulis Korespondensi: dedyfrianto@ubpkarawang.ac.id
}

\begin{abstract}
ABSTRAK
Kanker serviks merupakan kanker peringkat kedua yang sering didiagnosa pada wanita selama tahun 2018, berdasarkan data dari WHO di perkirakan ada 569.800 kasus baru yang timbul di seluruh dunia. Peningkatan kematian akibat kanker serviks yang diduga disebabkan keterlambatan dalam penanganan. World Health Organization (WHO) sebagai organisasi Kesehatan dunia telah merekomendasikan bahwa vaksin HPV dapat dilakukan pada anak perempuan dengan usia 9-13 tahun. Penelitian ini bertujuan untuk mengetahui sosiodemografi dan pengaruh keyakinan kesehatan tentang kanker serviks terhadap penerimaan vaksin sehingga dapat dijadikan sebagai suatu bahan penentu kebijakan. Pendekatan yang digunakan dalam penelitian ini adalah pendekatan observasional dengan model rancangan penelitian cross sectional. Responden yang telah mengisi lembar persetujuan mengisi kuisioner yang diadapatasi dari penelitian sebelumnya yang sudah dilakukan di Indonesia. Hasil analisis statistik dengan regresi logistik menunjukkan hasil bahwa faktor keyakinan kesehatan tentang kanker serviks menunjukan tidak ada pengaruh yang signifikan terhadap penerimaan Vaksin HPV dengan nilai sig 0,904 $(>0,05)$, sedangkan salah satu faktor sosiodemografi yaitu faktor pendidikan mempengaruhi penerimaan terhadap vaksin HPV dengan nilai sig $0,010(<0,05)$.
\end{abstract}

Kata kunci: Kanker Serviks, Penerimaan, Vaksin HPV 


\title{
THE EFFECT OF HEALTH BELIEFS ABOUT CERVICAL CANCER ON ACCEPTANCE OF HPV VACCINE SDN LEMAHDUHUR I AND SDN TUNGGAKJATI II IN KARAWANG DISTRICT
}

\begin{abstract}
Cervical cancer is the second most commonly diagnosed cancer in women during 2018, based on data from WHO, it is estimated that 569,800 new cases have arisen worldwide. The increase in deaths from cervical cancer is thought to be due to delays in treatment. The World Health Organization (WHO) as a world health organization has recommended that the HPV vaccine be administered to girls aged 9-13 years. Knowing the sociodemography and the influence of health beliefs about cervical cancer on vaccine acceptance so that it can be used as a policy determinant. The approach used in this study was an observational approach with a cross sectional study design model. Respondents who have filled in the consent form fill out a questionnaire adapted from previous research that has been conducted in Indonesia. The results of statistical analysis with logistic regression showed that the health belief factors about cervical cancer showed no significant effect on the acceptance of the HPV vaccine with a sig value of 0.904 (>0.05), while one of the sociodemographic factors, namely education, influenced acceptance of the HPV vaccine with a sig value of $0.010(<0.05)$.
\end{abstract}

Keywords: Cervical Cancer, Acceptance, HPV vaccine

\section{PENDAHULUAN}

Kanker serviks merupakan kanker nomor dua yang sering didiagnosa pada wanita di negara miskin dan berkembang selama tahun 2018, berdasarkan data dari WHO di perkirakan ada 569.800 kasus baru yang timbul di seluruh dunia. Kanker serviks juga penyebab kematian ke empat pada wanita di seluruh dunia dengan jumlah diperkirakan 311.400 pada tahun 2018. Berdasarkan Globocan tahun 2018 jumlah persentase dari kasus kejadian kanker serviks yaitu sebanyak 17,2\% (Bray, 2019). Indonesia memiliki jumlah penderita penyakit kanker serviks terbanyak kedua 10 kanker terbanyak berdasar data yang diperoleh dari bidang Patologi Anatomi tahun 2010 dengan insidens sebesar 12,7\%, menurut perkiraan Kementerian Kesehatan RI saat ini, jumlah wanita penderita baru kanker serviks berkisar 90-100 kasus per 100.000 penduduk dan setiap tahun terjadi 40 ribu kasus kanker serviks (Kemenkes RI, 2016).

Berdasarkan hasil Riset Kesehatan Dasar menunjukkan bahwa pada tahun 2013 terdapat 98.692 penderita kanker serviks di Indonesia, dan Infodatin menunjukkan peningkatan jumlah kematian akibat kanker serviks di Rumah Sakit Kanker Dharmais pada tahun 2011 hingga 2013. Pada tahun 2011 terjadi 35 kematian, tahun 2012 terjadi 42 kematian dan tahun 2013 terjadi 65 kematian. Prevalensi penderita kanker serviks di Jawa Barat yaitu menempati urutan kedua setelah Jawa Tengah yaitu dengan jumlah 
penderita kanker serviks sebanyak 15.635 orang (Kemenkes RI. 2015), sedangkan berdasarkan hasil SIRSHS (Sistem Informasi Rumah Sakit Hasan Sadikin) Kabupaten Karawang menempati urutan ketiga yang penduduknya menderita kanker serviks berdasarkan jumlah rujukan dari Januari 2018 hingga Desember 2018 sebanyak 60 orang pasien rujukan kanker serviks (SIRSHS, 2019).

Sebuah penelitian kanker serviks multinasional menemukan bahwa lebih dari 90\% hampir semua dari kanker serviks yang terjadi di seluruh dunia diakibatkan oleh 8 jenis tipe virus HPV yaitu tipe $16,18,31,33,35,45,52$, dan 58. Sedangkan tiga jenis tipe yaitu tipe 16 , 18, dan 45 mengakibatkan 94\% adenokarsinoma serviks. HVP tipe 16 dan 18 dapat menimbulkan risiko kanker serviks paling tinggi dibandingkan tipe HPV jenis lainnya (Murillo et al., 2016).

Dalam hal ini terjadinya peningkatan kematian akibat kanker serviks yang diduga disebabkan keterlambatan dalam penanganan (Rio, 2017). Meskipun ganas dan dapat menyebabkan kematian, kanker serviks dapat dicegah, pencegahan dapat dilakukan dengan berbagai cara seperti mengontrol perilaku seksual diri sendiri dan pasangan, memperhatikan kontrasepsi yang digunakan, tidak merokok, serta mengkonsumsi makanan yang bergizi.
Kanker serviks ini sangat berhubungan erat dengan HPVdan infeksi virus ini dapat dicegah dengan melakukan vaksinasi. Selain itu upaya deteksi dini juga dapat dilakukan, yaitu dengan menjalani tes Inspeksi Visual Asam Asetat (IVA) dan tes Pap Smear, Visual Inspeksi Lugol Iodin (VILI), Tes DNA HPV (Kemenkes RI, 2016). Untuk pencegahan dan pengendalian kanker di Indonesia, khususnya kanker serviks, pemerintah telah melakukan berbagai upaya antara lain deteksi dini kanker serviks pada perempuan usia 30-50 tahun dengan menggunakan metode pemeriksaan Inspeksi Visual dengan Asam Asetat (IVA) untuk leher Rahim atau serviks (Kemenkes RI. 2013). Kanker serviks dapat dicegah dengan memberikan vaksin HPV pada anak perempuan. Selain itu, jika terdeteksi dini dan diobati lebih dini, kanker serviks masih bisa disembuhkan (WHO, 2014).

World Health Organization (WHO) sebagai organisasi Kesehatan dunia telah merekomendasikan bahwa vaksin HPV dapat dilakukan pada anak perempuan dengan usia 9-13 tahun. Pada Anak perempuan yang akan menerima vaksin HPV yaitu diberikan dosis pertama sebelum usia 15 tahun dapat diberikan 2 kali jadwal pemberiannya. Adapun Interval yang diberikan antara masingmasing dosis yaitu jarak enam bulan. 
Tidak ada aturan jarak pemberian maksimum antara salah satu dosis, akan tetapi disarankan agar jarak kurang lebih tidak dari 12-15 bulan. Apabila jarak pemberian antara dosis kurang dari enam bulan, maka dosis berikutnya harus diberikan setidaknya enam bulan setelah dosis pertama. Adapun seseorang yang menderita gangguan dengan imun, termasuk orang yang menderita penyakit HIV, dan seorang wanita yang memiliki usia 15 tahun atau lebih juga harus diberikan vaksin sebanyak tiga dosis (pada 0, 1-2, dan 6 bulan) untuk sepenuhnya dapat melakukan pencegahan (WHO, 2014).

Pencegahan lebih efektif dilakukan dari pada melakukan pengobatan. Upaya preventif merupakan perilaku terkait dengan kesehatan individu yang dikenal dengan istilah health behaviour (perilaku sehat) hal itu dapat berpengaruh terhadap penerimaan vaksin HPV (Rio, 2017). Besarnya angka kejadian kanker serviks baik secara global, nasional maupun secara lokal, maka perlu dilakukan tindakan pencegahan dengan pemberian vaksin HPV, akan tetapi penerimaan orang tua sebagai pengambilan keputusan dapat dipengaruhi berbagai faktor diantaranya faktor pengetahuan, sikap, keyakinan dari orang tua atau anak itu sendiri dan faktor-faktor lain yang dapat ikut mempengaruhi. Keyakinan individu terhadap penyakit dan resiko yang akan ditimbulkan dari kanker serviks akan menjadi motor penggerak apakah dia akan melakukan upaya preventif atau tidak.

Oleh karena itu peneliti ingin mengetahui bagimana pengaruh keyakinan kesehatan yang dimiliki orang tua tentang kanker serviks terhadap penerimaan vaksin HPV di kabupaten Karawang yang diketahui angka kejadian kanker serviks cukup tinggi.

\section{METODE PENELITIAN}

Pendekatan yang digunakan dalam penelitian ini adalah pendekatan observasional dengan model rancangan penelitian cross sectional. Target responden dalam penelitian yang dilakukan ini ditentukan menggunakan metode area sampling dengan menentukan frame area di kabupaten karawang, kemudian menentukan sekolah yang yang menjadi target secara acak, semua orang tua siswi kelas 5 dan 6 di SD yang telah dipilih menjadi populasi yang akan dijadikan responden pada penelitian ini.

Pengumpulan data dari responden menggunakan lembar kuesioner yang telah disiapkan dan diadaptasi dari penelitian sebelumnya, serta dilakukan uji pendahuluan untuk menguji validitas an reabilitas kuisioner tersebut, setelah itu dilakukan pengambilan data dengan 
pengisian kuisioner secara bersama-sama di masing-masing sekolah. Bagian pertama kuisioner berupa data sosio- demografi responden, dan bagian kedua yaitu keyakinan kesehatan tentang kanker serviks.

\section{HASIL PENELITIAN}

\section{Sosiodemografi}

Tabel 1. Karakteristik Sosiodemografi Responden

\begin{tabular}{|c|c|c|}
\hline Sosio-demografi & Frekuensi & Persentase (\%) \\
\hline \multicolumn{3}{|l|}{ Agama } \\
\hline Islam & 100 & $92.59 \%$ \\
\hline Kristen & 0 & $0 \%$ \\
\hline Protestan & 0 & $0 \%$ \\
\hline Hindu & 0 & $0 \%$ \\
\hline Budha & 0 & $0 \%$ \\
\hline Tidak menjawab & 8 & $7.41 \%$ \\
\hline \multicolumn{3}{|l|}{ Pendidikan } \\
\hline Low (SD) & 52 & $48,15 \%$ \\
\hline Intermediate (SMP-SMA) & 38 & $35,18 \%$ \\
\hline High (Universitas) & 7 & $6,48 \%$ \\
\hline Tidak menjawab & 11 & $10,19 \%$ \\
\hline \multicolumn{3}{|l|}{ Usia } \\
\hline $23-31$ & 30 & $27,8 \%$ \\
\hline $32-36$ & 22 & $20,4 \%$ \\
\hline $37-58$ & 28 & $25,9 \%$ \\
\hline Tidak menjawab & 28 & $25,9 \%$ \\
\hline \multicolumn{3}{|l|}{ Jenis Kelamin } \\
\hline Perempuan & 108 & $100 \%$ \\
\hline Laki-laki & 0 & $0 \%$ \\
\hline \multicolumn{3}{|l|}{ Pekerjaan } \\
\hline Pegawai Negeri & 1 & $0,9 \%$ \\
\hline Pegawai Swasta & 8 & $7,4 \%$ \\
\hline Ibu Rumah Tangga (IRT) & 82 & $76 \%$ \\
\hline Tidak menjawab & 17 & $15,7 \%$ \\
\hline
\end{tabular}


Tabel 2. Pengaruh Keyakinan Kesehatan Tentang Kanker Serviks

\begin{tabular}{lcc}
\hline Keyakinan & Total & \% (Jawaban) \\
\hline Kanker serviks adalah penyakit yang berbahaya & \\
\hline Sangat setuju & 63 & $58,4 \%$ \\
Setuju & 42 & $38,9 \%$ \\
Tidak setuju & 1 & $0,93 \%$ \\
Sangat tidak setuju & 1 & $0,93 \%$ \\
Tidak ada jawaban & 1 & $0,93 \%$ \\
\hline Kanker serviks menyebabkan masalah fisik & \\
\hline Ya & 97 & $10,19 \%$ \\
Tidak & 11 & $87,81 \%$ \\
\hline Kanker serviks menyebabkan stress & & $12,96 \%$ \\
\hline Ya & 94 & $04 \%$ \\
Tidak & 14 & $2,78 \%$ \\
\hline Apakah anda takut/khawatir jika anak anda akan menderita kanker serviks ? & $76,85 \%$ \\
\hline Sangat setuju & 83 & $20,37 \%$ \\
Setuju & 22 & $0 \%$ \\
Tidak setuju & 0 & 0 \\
Sangat tidak setuju & 0 & \\
Tidak ada jawaban & 3 & \\
\hline
\end{tabular}

Tabel 3. Hubungan Antara Agama, Pendidikan Terakhir dan Keyakinan

\begin{tabular}{llcccc}
\hline No & Categorical factors & Sig & Odds Ratio & \multicolumn{2}{c}{ Confidence Interval 95 \% } \\
\hline 1 & Agama & 0,924 & 0,878 & 0,060 & 12,793 \\
2 & Pendidikan & $0,010^{*}$ & 3,661 & 1,366 & 9,813 \\
& & & & & \\
\hline No & Numerical Factor & Sig & Odds Ratio & Confidence Interval 95 \% \\
\hline 1 & Keyakinan & 0,904 & 0,956 & 0,458 & 1,995
\end{tabular}




\section{PEMBAHASAN}

Berdasarkan hasil analisis deskriptif dapat dilihat dalam tabel 1 . berdasarkan karakteristik penelitian ini agama bahwa agama islam adalah agama mayoritas yang dianut oleh responden karena sebanyak $92 \quad \% \quad$ responden beragama islam hal ini sesuai dengan penelitian yang dilakukan oleh Jasper, Sedangkan karateristik responden dalam Pendidikan yaitu sebanyak 35,18\%, Pendidikan dengan kategori Intermediate yaitu SMP-SMA 48,15 \%, sedangkan kategori high yaitu Universitas sebanyak $6,48 \%$ dan hal ini menggambarkan bahwa tingkat Pendidikan responden cukup tinggi karena hampir setengan dari jumlah responden memiliki tingkat pendidikan intermediate yaitu pendidikan SMP dan SMA, hal ini sejalan dengan penelitian Endarti. Karakteristik pada usia hampir memiliki persentase yang sama sesuai kategori penggolongan usia yaitu hampir semua kategori diatas $20 \%$ dengan persentase masing-masing kategori usia 23-31 sebanyak $30 \%$, kategori usia 32-36 sebanyak 20,4 \% dan kategori Usia 37-58 sebanyak 25,9 \%.

Pada hasil analisis jenis kelamin bahwa $100 \%$ responden yang menjawab kuesioner adalah perempuan karena hampir semua responden adalah ibu dari siswi dan hal ini sesuai dengan hasil penelitian jasper yang sesuai bahwa responden yang didominasi oleh jenis kelamin perempuan, dan pekerjan sebagian besar ibu rumah tangga (76\%).

Berdasarkan hasil uji Statistik dengan metode regresi logistik diperoleh hasil pengaruh Agama terhadap penerimaan Vaksin HPV memiliki sig $>0,05$ yang tidak signifikan sedangkan Pengaruh Pendidikan terhadap Penerimaan Vaksin HPV cukup signifikan dengan Nilai sig $<0,05$. Sedangkan pada faktor keyakinan memiliki nilai sig 0,904 nilai dengan $\mathrm{p}>0,05$ sehingga bisa diperoleh kesimpulan tidak ada pengaruh signifikan antara keyakinan Kesehatan Kesehatan Tentang Kanker Serviks terhadap Penerimaan Vaksin HPV SDN Lemahduhur I dan SDN Tunggakjati II di Kabupaten Karawang. 


\section{KESIMPULAN}

Berdasarkan hasil penelitian maka diperoleh kesimpulan bahwa Data sosiodemografi responden menunjukan bahwa agama mayoritas responden beragama Islam, pendidikan responden mayoritas intermediate yaitu pendidikan menengah SMP dan SMA, dan Pekerjaan mayoritas Ibu rumah tangga. Faktor keyakinan kesehatan tentang kanker serviks dengan analisis Regresi Logistik menunjukan tidak ada pengaruh yang signifikan terhadap penerimaan Vaksin HPV, sedangkan faktor pendidikan mempengaruhi penerimaan terhadap vaksin HPV.

\section{DAFTAR PUSTAKA}

Bray, F. 2019. Indonesia GLOBOCAN 2018. The Global Cancer Observatory, 256, 1-2.
Kemenkes RI. 2013. Riset Kesehatan Dasar 2013. Laporan Nasional 2013.

Kemenkes RI. 2015. Infodatin Pusat Data dan Informasi. Jakarta: Kemenkes RI.

Kemenkes RI. 2016. Metode Penelitian. Jakarta: Kemenkes RI.

Murillo, R., Herrero, R., Sierra, MS., and Forman, D . Cervical cancer in Central and South America: Burden of disease and status of disease control. Cancer Epidemiol, 2016, 44(Suppl 1): 121-130.

Rio, S. Persepsi tentang Kanker Serviks dan Upaya Prevensinya pada Perempuan yang Memiliki Keluarga dengan Riwayat Kanker. Jurnal Kesehatan Reproduksi, 2017, 4(3): 159-169.

SIRSHS. 2019. Daftar Rujukan Pasien Kanker Serviks Kabupaten Karawang.

WHO. 2014. Comprehensive Cervical Cancer Control. Geneva, 366-378. 